\title{
EDITORIAL political science in its european and global context
}

$\mathrm{P}$ olitical science is but one small cog in the vast Higher Education machine, and national systems of Higher Education cannot be fully understood outside of their European and global contexts. To understand the present state of our discipline, therefore, we need to be aware of the broader trajectory of Higher Education in Europe and the world, including, of course, its history and national traditions, since they go a long way to explaining where we have come from and where we are now. In a magisterial overview, Yves Mény ('Higher education in Europe: national systems, European programmes, global issues') does precisely this, showing how national traditions have mapped onto - as well as partially resisted - processes of Europeanisation and globalisation, producing a European Higher Education area which is undergoing fundamental change (primarily along increasingly competitive and 'American' lines) but one, nevertheless, that is moving at different rates in different countries and is hesitant and uncertain in many. The European Union (EU), which is effectively powerless in the field of education, has nevertheless been able to influence the Higher Education agenda by acting on general principles, which it holds dear, such as freedom of movement/circulation, competitiveness and harmonisation.

Bob Reinalda ('The ongoing Bologna process and political science') explores in greater depth one of these Europeaninspired processes of change, focusing on the implications and challenges of 'Bologna' for political science. He finds that 'Bologna', through 'its convergenceoriented action lines and policies', has had a clear impact on political science, largely through the profession's response in formulating a minimum definition of the discipline and of what students should expect to study if they take a political science degree. Yet, if this has been managed without 'Bologna' being seriously questioned, the process, Reinalda argues, embodies two further challenges - in relation to the need for interdisciplinarity and the shift from teacher-oriented to student-oriented approaches to learning - which will test political science in much greater ways (and particularly in relation to its core identity), and he questions whether the discipline is organised strongly enough to cope with these challenges.

Of course, Europeanisation is part of a broader process of globalised, marketdriven change. In order to survive and thrive in this process, Mény argues that countries and institutions need to have both the willingness and the ability to compete: in attracting the best students, teachers and administrators, in internationalising the faculty and curriculum and in attracting postgraduate researchers and post-doctoral fellows. The differences in relation to this willingness and ability, he argues, account for the current diversity of situations across Europe, and indeed determine whether different countries and their universities end up in the Premier League or just one of the many local leagues. In this perspective, Mény argues that 'Great Britain is the most advanced European country in that 
global trend', benefiting from two advantages over its Continental rivals: proximity to the American system and the 'natural monopoly' of the English language. Indeed, Mény cites the British model of change as a key factor in explaining Europe's own influence, with many European countries, originally 'shocked and appalled' by the British reforms, now borrowing various features from them.

Yet, while few would doubt that Britain is the most 'advanced' in terms of leading the pack, others might question whether all aspects of this trend constitute real 'advances'. So, while Reinalda explores the teaching dimension of the 'Europeanisation' process, Paul Taylor ('Perverted research and the political imagination') looks at the research dimension, and specifically research assessment in the UK that he (like Mény, conscious of the UK's leading role in this field) describes as 'a spectre...haunting Europe'. The RAE (Research Assessment Exercise) and its successor, the REF (Research Excellence Framework) (to be applied in 2014), have long been controversial across the British university sector. However, Taylor's interpretation of these processes as the expression of political and bureaucratic power provides the article with a focus on (even a pointing finger at) 'politically-aware disciplines' such as political science and sociology. Taylor finds it extraordinary that academics from political science and sociology, who have read authors such as Althusser, Weber and Marcuse, have failed to use their concepts and ideas to reflect on their own professional experiences. On the contrary, some have been 'supinely acquiescent' and the strongest advocates of the RAE process. However, rather than concluding simply that these academics should exploit (or should have exploited) their expertise better, Taylor suggests that political science, in fact, is insufficient in and of itself as an intellectual resource to under- stand the perversion and menace of research bureaucracy, and that political scientists should turn to literature instead to help them recover what they have lost 'in their perverted identification with the RAE's multifarious structures, rules, league tables, strategies etc'.

If Mény's picture of Europeanised/globalised change is accurate, then it raises the question of the extent to which political science is becoming 'Europeanised'. This question is being increasingly addressed in an explicit manner, as well as being implicit in much of what this journal publishes - perhaps inevitably in view of the original mission of the European Consortium for Political Research (ECPR), which Mény describes as 'one of the leading examples of the transformation of parochial scientific communities into a truly Pan-European organisation'. There are, of course, different ways in which one might approach the issue of whether there exists a specifically European political science (Bull, 2007), but there is no doubt that the organisational aspects are critical. As Mény notes, the example of the ECPR has, since the 1970s, been emulated by many, and Conor McGrath ('Increasing cooperation amongst political science associations') looks at a recent, and particularly ambitious, attempt to bring together into a confederation the various national political science associations, in order to promote and defend the discipline in Europe, facilitate communication and collaboration between national associations, and represent the interests of the discipline to policy makers. McGrath's article, however, is concerned less with narrating this story than in revealing, through a survey of seventeen national associations, the extraordinary diversity of these associations in terms of size, resources and activities undertaken. This diversity, of course, makes both the coming into being and successful operation of any confederation a difficult task; yet, the 
survey also reveals an evident consensus about the idea and the existence of the political will to achieve it.

While McGrath focuses on the organisational aspects of the question, Thibaud Boncourt ('Is European political science different from European political sciences?') explores the angle of research. Starting from the premise that, in institutional terms, a European political science has existed for thirty years now, in the form of the ECPR, he then proceeds to ask whether or not the ECPR's institutional achievement has been translated into a distinctive form of European academic research. He does this through an analysis of both the content and the authors of the ECPR's flagship journal, the European Journal of Political Research (EJPR) over a thirty-year period, comparing it to that of the two 'house' journals of the UK's and France's national political science associations: Political Studies and the Revue Française de Science Politique. While he finds a degree of convergence between the journals in terms of the representation of subfields, when it comes to methods 'huge differences appear between the national and the European level', with a much greater representation of comparative and quantitative methods in EJPR, which Boncourt puts down to French and British traditions, on the one hand, and the ECPR's initial guiding philosophy on the other, which was strongly influenced by American approaches. On the question of the ECPR's constitutional goal of 'fostering collaboration' and increasing contacts between European political scientists, Boncourt finds less evidence of achievement in the pages of the EJPR. While coauthorships in the EJPR are twice as frequent as those in the two national journals and while collaborations are more 'internationalised' in the EJPR, there remains, on the one hand, a strong tendency to collaborate with political scientists from the same country, and, on the other, a tendency of multinational authorships to involve transatlantic rather than intra-European collaborations, leading the author to conclude that 'European political science as embodied by the EJPR is a field only in the loose sense of the word'. Of course, this journal represents only one part of the ECPR's now rich and widespread published output, yet Boncourt's findings should give food for thought to those currently steering the organisation.

The nature of the articles in the teaching and professional sections make the subject of this issue's Symposium ('The development of a European public sphere') particularly pertinent. Edited by Cristiano Bee, Riccardo Scartezzini and Alan Scott, the symposium evaluates the current state of the European constitutional process, which they describe as having stalled since the signature of the Lisbon Treaty in December 2007. Starting from the premise (backed by social scientific evidence) that the popular perception of the European project as elitist 'may be rationally grounded' and that core state actors are the main beneficiaries from the integration process, the authors in the Symposium explore the challenges and difficulties involved in the social construction of Europe, or the creation of a European public sphere. The various articles reveal the complexity of this process, the significance to integration of fundamental concepts such as participation, democracy and transparency, and the difficulty of applying these to the different national traditions of European countries. Overall, the Symposium is not so much pessimistic as realistic in presenting the complexity of what the editors (echoing Claus Offe and Ulrich Preuss) describe as the EU's 'unique challenge of creating a polity in the absence of a demos'.

In the Research section, we are honoured to reproduce an article by Peter Hall ('Systemic process analysis') that first appeared in the European Management 
Review, a journal that, we suspect, may not appear on many political scientists' reading lists. We were keen to seek to republish this article (for which we gratefully acknowledge the permission granted by Peter Hall and the European Academy of Management) because we feel it speaks very much to a core part of the European political science tradition: small- $n$ comparative research designs. Hall emphasises that this approach should not be viewed as the 'weak sister of statistical methods'; on the contrary, he explains how much they are to be valued, if accompanied by a method that he defines as 'systemic process analysis'. In doing so, he is not so much proposing the adoption of a 'new' method as justifying (at the same time as refining) an approach that has long been popular among political and social scientists in Europe.

Featherstonehaugh and Cholmondeley ('Urban Politics and Sex at Birth'), by contrast, appear to be drawing on a very different tradition in European political science (see, e.g., Schneider, 2007; Taagepera, 2007; Lehrer et al., 2007; Budge, 2007). While it may be true, as the authors argue, that 'there is very little research on the significance of politics for sex at birth', some readers may question the causal direction posited by the statistical regressions used for the analysis. Still, as one of the anonymous referees of this article noted, 'the larks have it'.

martin bull and james newell University of Salford

\section{References}

Budge, I. (2007) 'Uses and abuses of citation: how valid are the indices? and what are wider research implications?' European Political Science 6(3): 302-305.

Bull, M. (2007) 'Is there a European political science and, if so, what are the challenges facing it?' European Political Science 6(4): 427-438.

Lehrer, D., Leschke, J., Lhachimi, S., Vasilu, A. and Weiffen, B. (2007) 'Negative results in social science', European Political Science 6(1): 51-68.

Schneider, G. (2007) 'Why is European political science so unproductive and what should be done about it?' European Political Science 6(2): 156-159.

Taagepera, R. (2007) 'Why political science is not scientific enough', European Political Science 6(2): 111-113.

doi: $10.1057 /$ eps.2008.22 